$$
\text { 鉄筋コンクリートの打継部に形成するマクロセルへの }
$$

\author{
腐食速度解析モデルの適用
}

畑中 達郎* 宮里 心二**

\title{
Application of Corrosion Rate Analysis Model to Macrocell Formed at Joint in Reinforced Concrete
}

by

\author{
Tatsuro HATANAKA* and Shinichi MIYAZATO**
}

\begin{abstract}
Many reinforced concrete structures in Japan are aging. A reasonable and durable design by the numerical analysis is necessary to extend the service life of concrete structures. Based on the above background, this paper is applied the macrocell corrosion rate analysis model whom authors proposed to the members with a joint. First the model is constructed. The input data is an anode polarization curve, a cathode polarization curve, a polarization resistance, and an electrical resistance of mortar. On the other hand, the output data is a total corrosion current. Next, an analytical value is compared with the experiment value while using the mortar specimen that imitated the patch repair part. As a result, it can be cleared that the model is appropriate. Finally, the effect of the macrocell countermeasures method with the spray of the silane type surface penetrant on the joint is verified by this model. Thus, it can be confirmed that when the electrical resistance at the joint is large, the corrosion rate becomes low analytically.
\end{abstract}

Key words:

Reinforced concrete, Chloride induced corrosion, Macrocell corrosion rate, Analysis model, Joint

\section{1 緒言}

鉄筋コンクリートは，高い耐久性を有し，長期に亘り 利活用される。しかしながら，塩化物イオンがコンクリ 一ト中の鉄筋に浸透すると，不働態皮膜が破壊し，腐食 が発生する. 特に, 塩化物イオンの濃度差が生じる箇所, すなわち塩分環境下に立地する鉄筋コンクリートのひ び割れ部や, 母材の塩分除去が不十分な断面修復部では, マクロセルが形成し, その腐食速度は速いことが確認さ れている ${ }^{\left.1)^{2} 7\right)}$ 。この様な場所では，鉄筋が減肉して引張 耐力が減少したり, 鉄筋とコンクリートの付着力が低下 したりする. その結果, 部材耐力が低減し, 要求された 安全性や使用性を満足できなくなる。したがって, 高度 経済成長期に多数の鉄筋コンクリート構造物が建設さ れ, 一部の部材で劣化が進んでいる現代, 腐食による性 能低下も考慮した耐久設計や維持管理が必要である.

さて, コンピュータの性能向上により, 様々な分野に おいて, シミュレーションによる予測が可能になってき た. すなわち, 従来は実験や観測により現象を再現して いたが，現在はメカニズムをモデル化して現象を解析す るケースが増えている。例えば，天気予報に関しては， 富士山頂のレーザで気象観測する方法から, スーパーコ ンピュータを用いてシミュレーションする方法に変化 した．老朽化が進む日本の鉄筋コンクリート構造物に対
して，この様なシミュレーションを用いれば，再劣化を 予防した合理的な補修が可能になると思われる。

ここで，鉄筋コンクリートの腐食を解析するモデルを 整理する. 丸屋ら ${ }^{8)}$, J. Gulikers ${ }^{9)}$, ならびに著者ら ${ }^{10)}$ は, コンクリート中の鉄筋を要素に分割し, 各要素のアノー ド分極曲線とカソード分極曲線を交差させて平衡した 電流から, マクロセルおよびミクロセル腐食電流を解析 するモデルを提案している．この様なモデルを多様に整 備し，それぞれの長所と短所を比較することで，今後に 改良や統合をすれば，様々な材料や環境に対応した耐久 設計に関するシミュレーションが可能になる. そのため, 前述のモデル 10)では, ひび割れ部のマクロセル腐食を対 象にした適用可能性は確認しているが，打継部を対象と したケースは未検討であり, 検証が求められていた。特 に, 実験的検討によれば，打継目を境とした母材と補修 材の間の電気抵抗が大きいほど, マクロセル腐食速度は 遅くなることが確認されている ${ }^{11)}$ 。さらに，小松らによ り，打継面の電気抵抗を高めることで，断面修復後のマ クロセル腐食を抑制する補修方法が提案されている ${ }^{12)}$. したがって, もし前述のモデル 10)が打継部のマクロセル 腐食を解析できることを確認できれば，これらの実験事 実を解析によっても検証できる.

以上の背景を踏まえて本研究では, 著者らにより提案

$\dagger$ 原稿受理 平成29年1月10日 Received Jan.10, 2017 @2017 The Society of Materials Science, Japan

* 学生会員 金沢工業大学大学院 工学研究科 環境土木工学専攻 广924-0838 白山市八束穂

Graduate student, Department of Civil and Environmental Engineering, Kanazawa Institute of Technology, Yatsukaho, Hakusan, 924-0838.

** 正 会員 金沢工業大学 環境·建築学部環境土木工学科 $=924-0838$ 白山市八束穂

Department of Civil and Environmental Engineering, Kanazawa Institute of Technology, Yatsukaho, Hakusan, 924-0838. 
されたマクロセル腐食速度解析モデル ${ }^{10)}$ を，打継部に適 用できることを明らかにする。その上で，打継面へシラ ン系表面含浸材を塗布することによるマクロセル対策 工法 ${ }^{12)}$ の効果の検証に本モデルを適用し, 既往の実験結 果を確認する.

\section{2 解析モデルの概要}

モデルの概要を説明する. なお, 基本的なコンセプトは, ひび割れ部のマクロセル腐食を対象にした既往の論文 ${ }^{10)}$ と同様である。

本研究では，狭い範囲でアノードとカソードが連結し た腐食回路による「ミクロセル腐食電流」と, 広い範囲で アノードとカソードが連結した腐食回路による「マクロ セル腐食電流」を合計することにより，「総腐食電流」を 算定する ${ }^{13)}$. そのため, モデルの最終的なアウトプット データは「総腐食電流」である。一方, インプットデータ は, 各鉄筋要素の「アノード分極曲線」,「カソード分極曲 線」,「分極抵抗」, および「鉄筋要素間のモルタルの電気 抵抗」である。

これを踏まえて先ずは，マクロセル腐食電流とミクロ セル腐食電流を区別して解析するため，鉄筋を要素に分 割する. すなわち, Fig.1 に示すとおり, 一本の鉄筋は複 数の鉄筋要素の連続体として考える.また, アノードとカ ソードが, 単一の鉄筋要素内に存在する場合を「ミクロセ ル」とし，一方異なる鉄筋要素に跨る場合を「マクロセル」 とする。

次に, 打継部を対象にした解析手順を説明寸る.アノー ド分極曲線およびカソード分極曲線の組合せとマクロセ ル腐食電流およびミクロセル腐食電流の関係を, Fig.2 に 示す. Fig.2(1)に示すとおり, 鉄筋要素(2)は母材等の塩化 物イオンを含有するモルタル内部に存在し，一方鉄筋要 素(3)は補修材等の塩化物イオンを含有しないモルタル内 部に存在すると仮定する.ここで, 左右のモルタルでは, 塩化物イオン含有量や水セメント比が異なる. そのため, 塩化物イオン量の影響を受けるアノード分極曲線, およ び酸素供給量の影響を受けるカソード分極曲線は，鉄筋 要素(2)と鉄筋要素(3)で異なる ${ }^{14)}$.

また，アノード分極曲線とカソード分極曲線の交点が 電気化学的な平衡状態であり，この電流值で腐食反応は 制御される ${ }^{15)}$. ここで, Fig.2(2)に示すとおり, 同一鉄筋 要素内（Fig.2(2)の例では鉄筋要素(2)）にアノードとカソ 一ドが形成されるミクロセルの場合，対象とする鉄筋要 素の見掛けの分極抵抗に伴う電位口スを考慮する必要が ある.すなわち, アノード分極曲線とカソード分極曲線の 交点よりも左側（腐食電流が小さい側）において, 式(1)の オームの法則を満足するミクロセル腐食電流が流れる.

$\mathrm{E}_{\mathrm{C}(2)}-\mathrm{E}_{\mathrm{A}(2)}=\left(\mathrm{R}_{\mathrm{P}(2)}+\mathrm{R}_{\mathrm{P}(2)}\right) \times \mathrm{I}_{\text {micro }}$

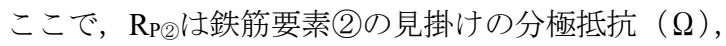

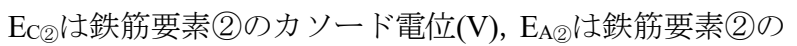
アノード電位 $(\mathrm{V})$ を示す.

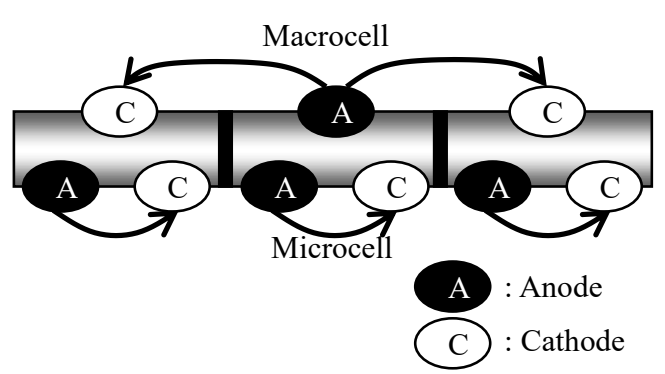

Fig.1 Divided steel element and corrosion cell.

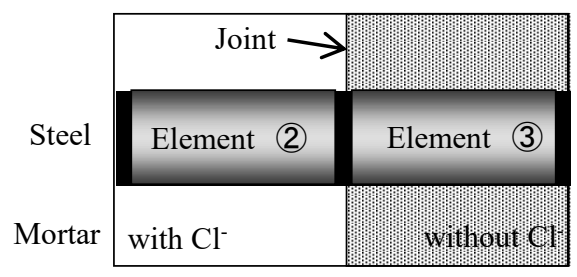

(1) Location of steel element

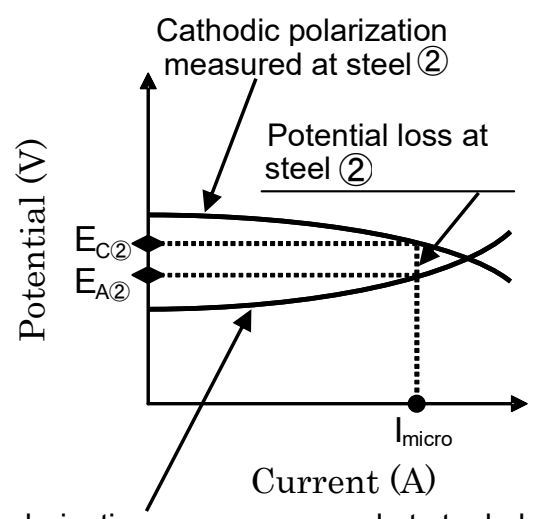

Anodic polarization curve measured at steel element (2)

(2) Microcell formed in steel element (2)

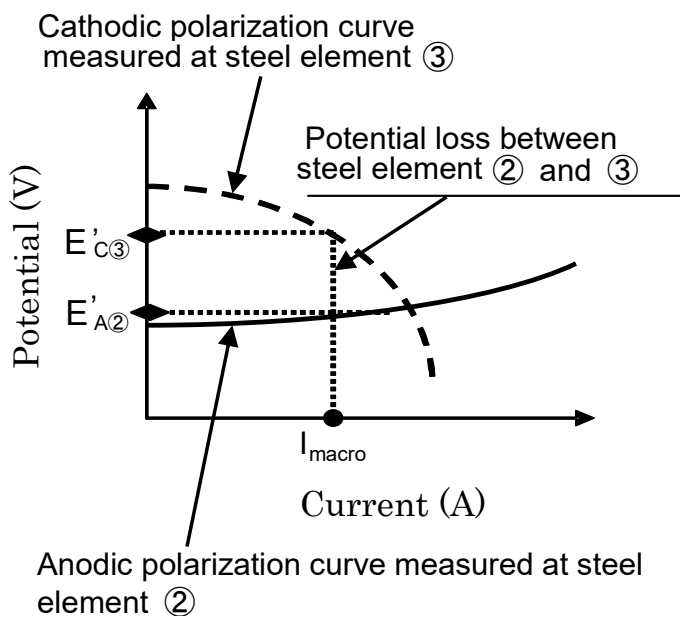

(3) Macrocell formed between steel elements (2) and (3)

Fig.2 Relationship between polarization curves and corrosion current. 
一方, Fig.2(3)に示すとおり, 異なる鉄筋要素 (Fig.2(3) の例では鉄筋要素(2)と(3)）に跨ってアノードとカソード が形成されるマクロセルの場合，対象とする鉄筋要素(2) と (3)の見掛けの分極抵抗や両鉄筋要素の間のモルタル 抵抗に伴う電位口スも考慮する必要がある. すなわち, アノード分極曲線とカソード分極曲線の交点よりも左 側（腐食電流が小さい側）において, 式（2）のオームの 法則を満足するマクロセル腐食電流が流れる.

$$
\mathrm{E}_{\mathrm{C}(3)}^{\prime}-\mathrm{E}_{\mathrm{A}(2)}^{\prime}=\left(\mathrm{R}_{\mathrm{P}(3)}+\mathrm{R}_{\mathrm{C}(2)(3)}+\mathrm{RP}_{\mathrm{P}(2)}\right) \times \mathrm{I}_{\text {macro }}
$$

ここで， $\mathrm{R}_{\mathrm{P}(3)}$ は鉄筋要素(3)の見掛けの分極抵抗 $(\Omega), \mathrm{R}_{C}$ (2)(3)鉄筋要素(2)と(3)の間のモルタル抵抗 $(\Omega), \mathrm{E}^{\prime}(3)$ は鉄 筋要素(3)のカソード電位(V), E'A(2)鉄筋要素(2)のアノー ド電位 $(\mathrm{V})$ を示す.

\section{3 検証実験}

\section{1 実験手順}

3.1 .1 供試体概要 供試体概要を Fig.3 に示寸. 多量の塩 化物イオンを含有する母材部（左側）と，塩化物イオンを 含有しない打継部（右側）を接合した。母材部には鉄筋要 素(1)と(2)を，一方打継部には鉄筋要素(3)を，かぶり $20 \mathrm{~mm}$ に埋設した。なお，モルタルの配合は，W/C が $50 \%$ で， $\mathrm{S} / \mathrm{C}$ が 3.0 とした，接合部を補強するため，供試体側面(幅 $10 \mathrm{~mm})$ にエポキシ樹脂を被覆した.

母材部を打設後，4 週間に亘り湿潤気中 $\left(20^{\circ} \mathrm{C} ， 90 \% \mathrm{RH}\right)$ で養生した。 その後，打継部を接合し，1 週間に亘り湿潤 気中養生を兼ねた暴露を行った. 2 週目以降は温度を $40^{\circ} \mathrm{C}$ として 13 週目まで暴露した.

なお， 3 体の同種の供試体を作製し，実験および解析に 用いた。

3.1 .2 測定概要 Fig.4 に示すとおり, 鉄筋要素のカソー ドおよびアノード分極曲線, 鉄筋要素の分極抵抗, 鉄筋要 素間のモルタルの電気抵抗，および鉄筋要素間のマクロ セル腐食電流を暴露 13 週後に測定した。 なお，ミクロセ ル腐食電流の実験值は，分極抵抗の測定值を用い，文献 13)を参考に算定した.

(1) 鉄筋要素のカソードおよびアノード分極曲線

$\mathrm{Ag} / \mathrm{AgCl}$ を参照電極として, 鉄筋要素の電位を強制的に $1 \mathrm{mV} /$ 秒で卑へ変化させ，その時に流れる電流をカソード 分極曲線として記録した. 続いて, 鉄筋要素の電位を強制

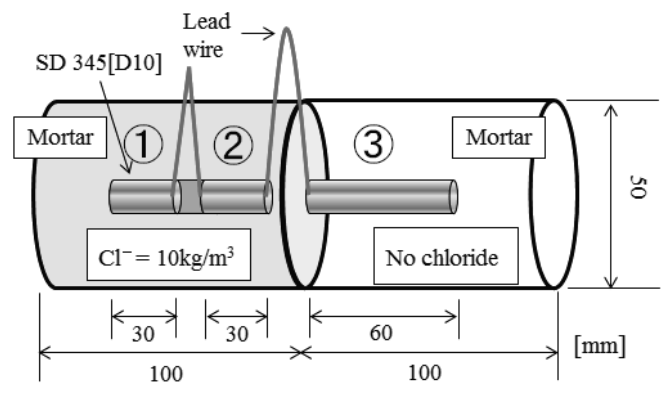

Fig.3 Specimen.
的に $1 \mathrm{mV} /$ 秒で貴へ変化させ，その時に流れる電流をアノ ード分極曲線として記録した. なお，カソード分極曲線と アノード分極曲線は同じ試料を用いて，連続的に測定し た.

(2) 鉄筋要素の分極抵抗

交流インピーダンス法により各鉄筋要素の分極抵抗を 測定した。

(3) 鉄筋要素間のモルタルの電気抵抗

交流インピーダンス法により各鉄筋要素間のモルタル の電気抵抗を測定した.

(4) マクロセル腐食電流

鉄筋要素間に流れるマクロセル腐食電流を無抵抗電流 計により測定した。

\section{2 解析手順}

3 体の内の 1 体の供試体を例に, 具体的な解析手順を説 明する。

インプットデータである，カソード分極曲線およびア ノード分極曲線を Fig.5 に，分極抵抗を Table 1 に，モル タルの電気抵抗を Table 2 に示す．なお，カソード分極曲 線とアノード分極曲線の低電流側における電位は，同じ 值になる測定結果が報告されている 16),17). ただし本実験 では，先に実施したカソード分極により電極表面で還元 体が消費され，その濃度が変化した状態でアノード分極 を実施した。したがって，アノード分極曲線の測定結果は

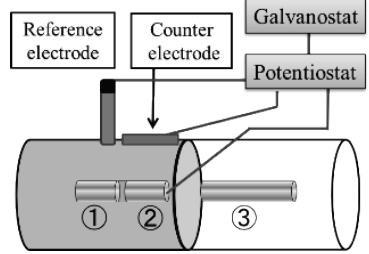

(1) Polarization curve

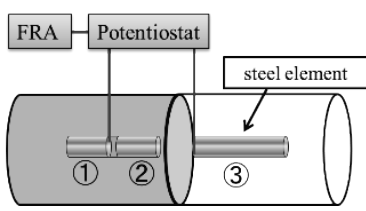

(3) Mortar resistance

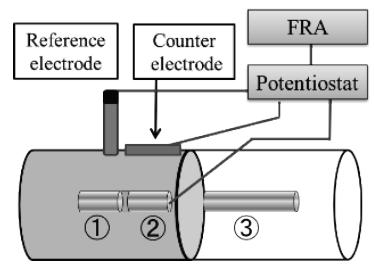

(2) Polarization resistance

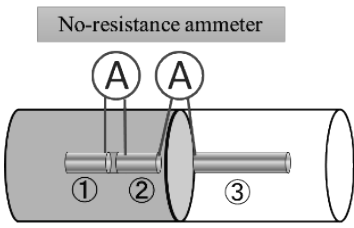

(4) Macrocell corrosion current
Fig.4 Measurement method.

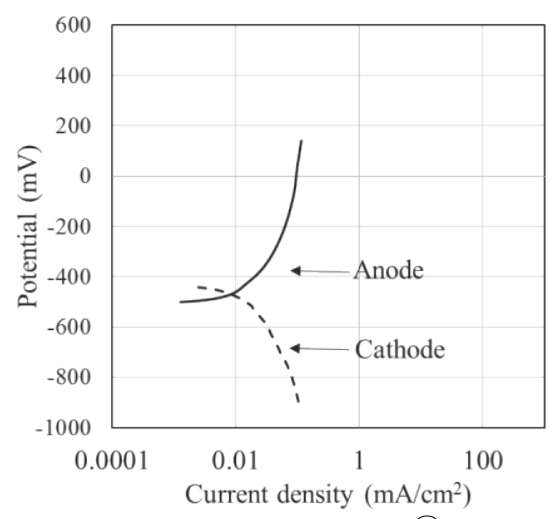

(1) Steel element (1)

Fig.5 Example of input data about polarization curve. 


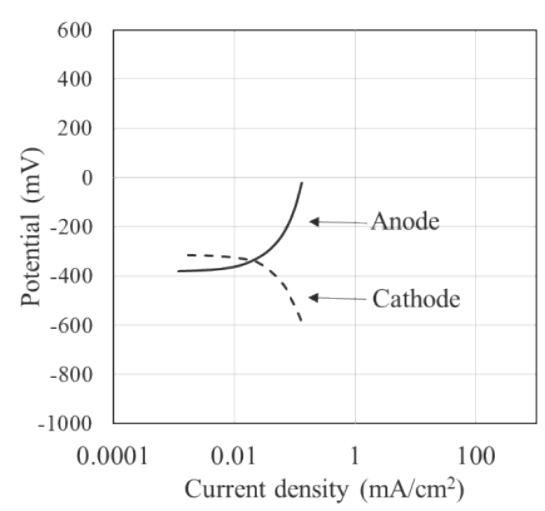

(2) Steel element (2)

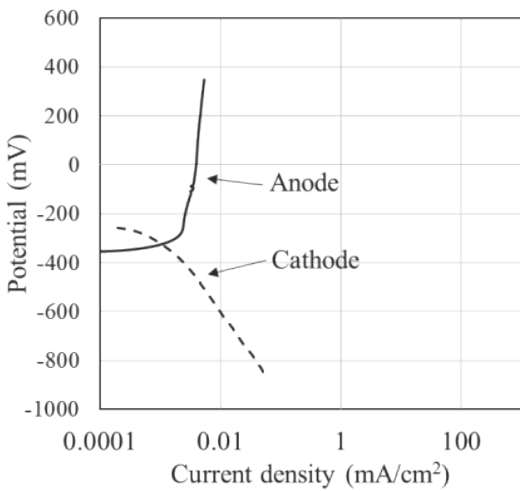

(3) Steel element (3)

Fig.5 Example of input data about polarization curve.

Table 1 Example of input data about polarization resistance.

\begin{tabular}{c|c}
\hline Steel element & Polarization resistance $\left(\mathrm{k} \Omega \cdot \mathrm{cm}^{2}\right)$ \\
\hline 1 & 3.4 \\
\hline 2 & 18.8 \\
\hline 3 & 1219.0 \\
\hline
\end{tabular}

Table 2 Example of input data about mortar resistance.

$(\mathrm{k} \Omega)$

\begin{tabular}{c|c|c|c}
\hline Steal element & 1 & 2 & 3 \\
\hline 1 & - & 0.9 & 1.8 \\
\hline 2 & 0.9 & - & 1.1 \\
\hline 3 & 1.8 & 1.1 & - \\
\hline
\end{tabular}

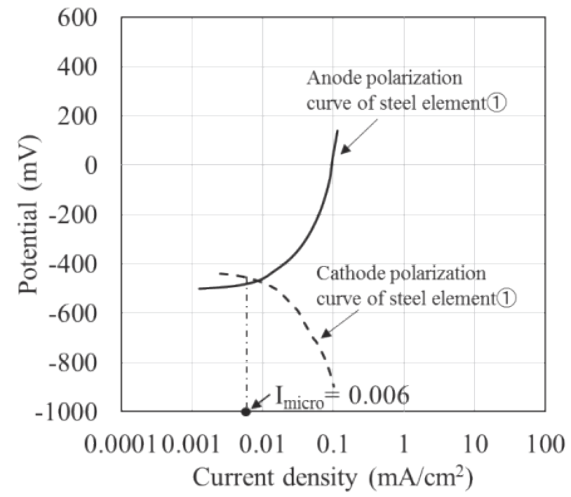

Fig.6 Example of analysis of microcell corrosion current. (steel element (1))

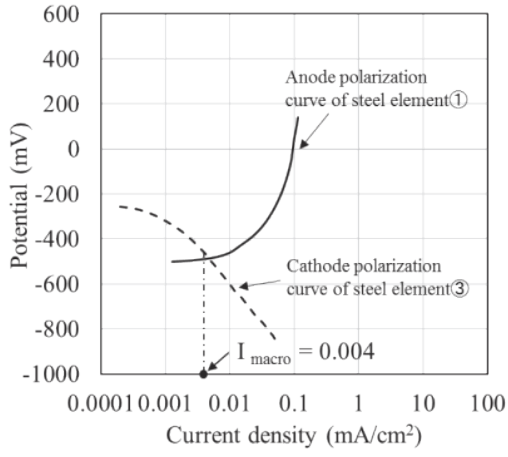

Fig.7 Example of analysis of macrocell corrosion current. (Anode: steel element (1), Cathode: steel element (3))

Table 3 Example of analyzed corrosion currents.

$(\mu \mathrm{A})$

\begin{tabular}{c|c|c|c|c}
\hline \multirow{2}{*}{ Steel element } & \multicolumn{3}{|c}{ Cathode } \\
\cline { 3 - 5 } \multicolumn{2}{c|}{} & 1 & 2 & 3 \\
\hline \multirow{2}{*}{$\&$} & 1 & 6 & 8 & 4 \\
\cline { 2 - 5 } & 2 & 4 & 4 & 3 \\
\cline { 2 - 5 } & 3 & 2 & 2 & 1 \\
\hline
\end{tabular}

Table 4 Example of outputted corrosion current density.

$\left(\mu \mathrm{A} / \mathrm{cm}^{2}\right)$

\begin{tabular}{c|c|c|c}
\hline Steel element & Microcell & Macrocell & Total \\
\hline 1 & 6 & 6 & 12 \\
\hline 2 & 4 & -3 & 4 \\
\hline 3 & 1 & -3 & 1 \\
\hline
\end{tabular}

その影響を受け，文献 16),17)に示される様な真值と差が 生じたと考えられる. すなわち, 両分極曲線の低電流側に おける電位が同等になると仮定すれば，真のアノード分 極曲線は Fig.5 に描かれる線より左上にシフトすると考え られ，その影響については Fig.9 で後述する.

次に，これらのインプットデータを用いた解析方法を 説明する. 先ずは, 任意の鉄筋要素についてアノード分極 曲線とカソード分極曲線を重ね合わせる. 例えば, Fig.6 の ようにミクロセルを対象とする際には, 同一の鉄筋要素

(Fig.6 の例では鉄筋要素(1)）のアノード分極曲線および カソード分極曲線を重站合わせる.また, 鉄筋要素(1)の見 掛けの分極抵抗の 2 倍を, アノードとカソードの間の電 気抵抗による電位ロスとして考慮する. そのため, ミクロ セル腐食電流は, 分極曲線の交差する点よりも左に移動 した, $0.006 \mathrm{~mA} / \mathrm{cm}^{2}$ となる. 一方, Fig.7 のようにマクロセ ルを対象とする際には，異なる鉄筋要素のアノード分極 曲線（Fig.6の例では鉄筋要素(1)）およびカソード分極曲 線（Fig.6の例では鉄筋要素(3)）を重ね合わせる.また, 鉄筋要素(1)の見掛けの分極抵抗と, 鉄筋要素(1)と (3)の間 のモルタルの電気抵抗，および鉄筋要素(3)の見掛けの分 極抵抗の和を，アノードとカソードの間の電気抵抗によ る電位ロスとして考慮する. そのため, マクロセル腐食電 流は, 分極曲線の交差する点よりも左に移動した, $0.004 \mathrm{~mA} / \mathrm{cm}^{2}$ となる. すべての鉄筋要素間において上述の 
解析をした結果, 各鉄筋要素間を流れる腐食電流は, Table 3 に示すとおりとなる.

さらに, 各鉄筋要素におけるマクロセルのアノードに なる場合の腐食電流からマクロセルのカソードになる場 合の腐食電流を差し引いた值が，マクロセル腐食電流に なる.したがって, 各鉄筋要素のマクロセル腐食電流とミ クロセル腐食電流は, Table 4 に示すとおりとなる. ここ で，腐食による鉄筋の減肉はアノード反応により進行す る. そのため, 正の值のマクロセル腐食電流とミクロセル 腐食電流を足し合わせた值が，総腐食電流になる.

\section{3 結果}

Fig. 8 に, 全 3 体の供試体における総腐食電流密度分布 の解析值と実験值を比較する。これによれば何れも, 塩化 物イオンを含有するモルタル内の鉄筋要素(1)において, 総腐食電流密度が高くなった。一方, 塩化物イオンを含有 しないモルタル内の鉄筋要素(3において, 総腐食電流密 度が低くなった。この様なマクロセルの形成は第 1 章に 示した既往の知見とも整合する.したがって, 本モデルに よる解析は, 打継部のマクロセル腐食の形成をシミュレ ーションできると判断した.

Fig.9 に，すべての供試体におけるすべての鉄筋要素で の, 総腐食電流密度の解析值と実験值を比較する.これに よれば，解析值と実験值は概ね等しいことが認められる. したがって, 本モデルによる解析は, 打継部のマクロセル 腐食電流を定量的にシミュレーションできると判断した。 なお, すべてのプロットは $1: 1$ の線より若干左上にあり， 解析值が実験值より僅かに大きい傾向を示している。こ れは, Fig.5 で前述の通り, アノード分極曲線の電流が大 きく測定された影響と考えられる.すなわち，もしアノー ド分極曲線が左上にシフトされれば, Fig.6 および Fig.7 に より解析されるマクロセル腐食電流とミクロセル腐食電 流は小さくなる. その結果, 解析值は実験值に近づくと考 えられる。

\section{4 マクロセル対策エの実験結果に対する検証 4.1 実験手順}

第 3 章と同様の供試体を用いた. ただし，母材モルタル の打設から 4 週間に亘り湿潤気中で養生した後に, 1 週間 に亘り乾燥 $\left(20^{\circ} \mathrm{C}, 60 \% \mathrm{RH}\right)$ させ, 打継面の表面水分率を $8 \%$ 以下に調整した。 それから既往の研究 18)で最も効果の高 かったシラン・シロキサン系含浸材を， $200 \mathrm{~g} / \mathrm{m}^{2}$ の量で打 継面に塗布した後, 1 週間に亘り乾燥気中で養生した. そ の後, アクリル系接着剤を塗布し, 約 3 時間に亘り気中乾 燥させた.さらに第 3 章と同様に打継部を接合し，1 週間 に亘り湿潤気中養生を兼祆た暴露を行った。 また 2 週目 以降は温度を $40^{\circ} \mathrm{C} と し て, 13$ 週目まで暴露した。

\section{2 解析に用いたインプットデータ}

鉄筋要素(1)と(3)の間で測定されたモルタルの電気抵抗 を Fig.10 に示す. これによると，含浸材を塗布すること により，モルタル抵抗が増加することを確認できる.

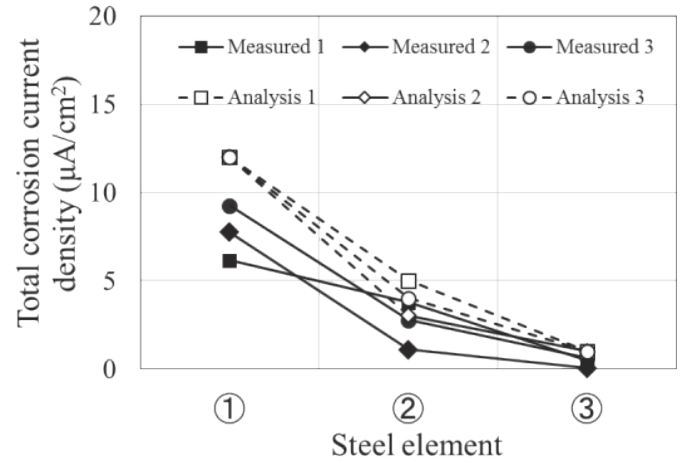

Fig.8 Distribution of analyzed and measured total corrosion current densities.

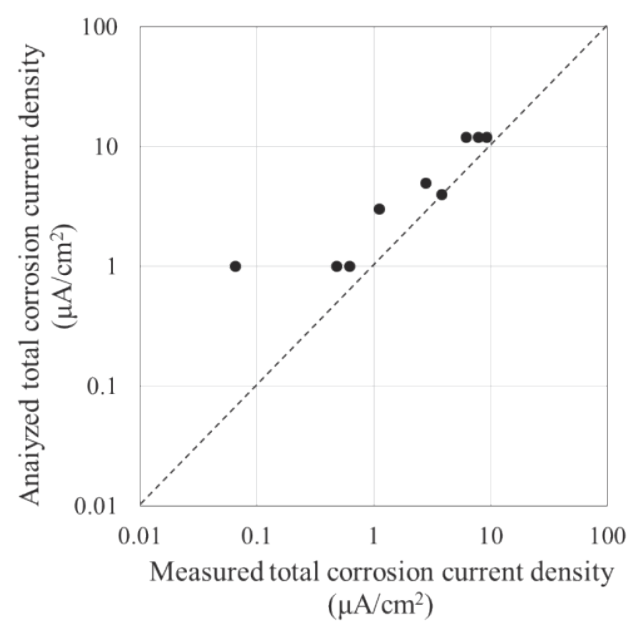

Fig.9 Comparison between analyzed and measured total corrosion current densities.

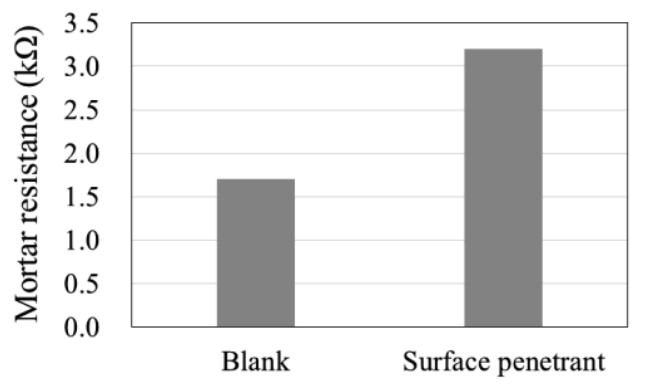

Fig.10 Mortar resistance between steel elements (1) and (3).

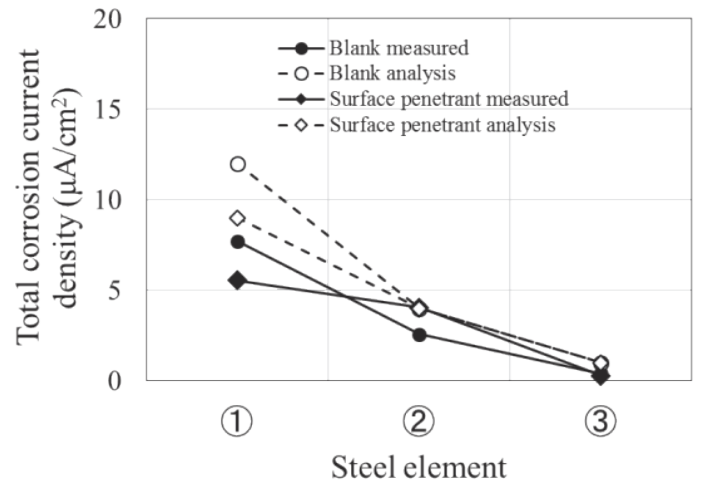

Fig.11 Distribution of analyzed and measured total corrosion current density for specimen with silane type surface penetrant on joint. 


\section{3 結果}

Fig.11 に, 表面含浸材の塗布の有無が総腐食電流密度分 布に及ぼす影響に関する, 解析值と実験值を示す。ここで, 無塗布の結果は, Fig.8の 3 体の結果の平均值を示す。こ れによれば, 解析值と実験值はともに, 表面含浸材を塗布 した場合に, 塗布しない場合と比較して, 総腐食電流密度 が低くなった。したがって，母材と補修材の間に表面含浸 材を塗布し，打継面の電気抵抗を高めることが再腐食を 抑制できることについて，既往の実験結果 12),18)のみなら す解析的にも確認された. Fig.12に, 総腐食電流密度の解 析值と実験值を比較する。 これによれば, 解析值と実験值 は概ね等しいことが認められる。したがって, 本モデルに よる解析は，打継部にマクロセル腐食対策工を実施する 場合にも，適用できることが明らかになった。

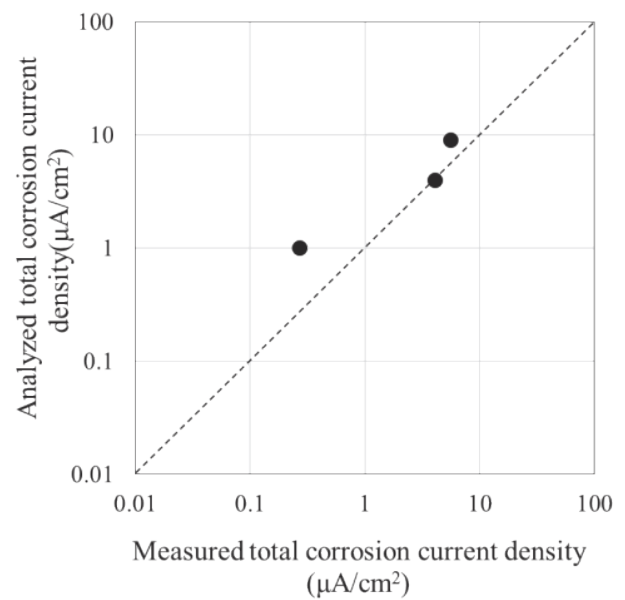

Fig.12 Comparison between analyzed and measured total corrosion current densities for specimen with silane type surface penetrant on joint.

\section{5 結 論}

本研究で得られた結論を以下に示す.

(1) 著者らにより提案されたマクロセル腐食速度解析 モデル 10)は，塩化物イオンの濃淡差がある打継部 にも適用できた。

（2）打継面へシラン系表面含浸材を塗布することによ るマクロセル対策工法の防食性は, 本モデルを用い た解析でも，既往の実験 12),18) と同様に効果を有す ることが確認できた。

今後, 事後保全として断面修復工法が適用される際, 本研究成果を踏まえて, 母材コンクリートと補修材の品 質を反映したインプットデータを用い，補修後のマクロ セル腐食電流を試算すれば，再劣化を抑制できる補修材 の選択が可能になる. また, 山口らの実験的研究 19)も考 慮して，犠牲陽極材を用いた流電陽極方式の電気防食を 実施する際に，本研究成果を踏まえて防食電流を試算す れば，最も効果の高い補修材の選択が可能になる.

\section{参考文献}

1) S. Nagataki, N. Otsuki, A. Moriwake and S. Miyazato, "The experimental study on corrosion mechanism of reinforced concrete at local repair part", Journal of JSCE, No.544, pp.109119 (1996).

2) T. Kawahigashi, K. Kobayashi and T. Miyagawa, "A study of macro-cell and micro-cell corrosion of steel in concrete", Journal of JSCE, No.732, pp.1-15 (2003).

3) H. Murakami, N. Ominda, Y. Kato and T. Uomoto, "Influence of cathodic area on macrocell corrosion rate", Proceedings of JSCE Annual Meeting, Vol.65, No.5, pp.411-412 (2010).

4) P. Schiessl, W. Breit and M. Raupach, "Durability of local repair measures on concrete structures damaged by reinforcement corrosion", Proceedings of 3rd CANMET ACI International Conference on Durability of Concrete, pp.11951215 (1997).

5) C. Andrade, I. R. Maribona, S. Feliu, J.A. González and S. Feliu $\mathrm{Jr}$, "The effect of macrocells between active and passive areas of steel reinforcements", Corrosion Science, Vol.33, No.2, pp.237-249 (1992).

6) J. Gulikers, "Experimental investigations on macro cell corrosion in chloride-contaminated concrete", Heron, Vol.41, No.2, pp.107-123 (1996).

7) M. Wasim and R. R. Hussain, "Experimental investigation of re-corrosion phenomenon in simulated repaired steel reinforced self consolidating concrete structures", International Journal of Electrochemical Science, No.8, pp.1678-1690 (2013).

8) T. Maruya, H. Takeda, K. Horiguchi, S. Koyama and K. L. Hsu, "Simulation of steel corrosion in concrete based on the model of macro-cell corrosion circuit", Journal of JSCE, Vol.62, No.4, pp.757-776 (2006).

9) J. Gulikers, "Numerical modeling of reinforcement corrosion in concrete", pp.71-90 (2005) Woodhead Publishing Ltd and CRC Press LLC

10) Y. Hasegawa, S. Miyazato, T. Oyamoto and K. Yokozeki, "Proposal of corrosion rate analytical model of reinforced concrete with crack", Journal of Concrete Research and Technology, Vol.17, No.1, pp.31-40 (2006).

11) S. Nagataki, N. Otsuki, A. Moriwake, T. Kamada and S. Miyazato, "Influence of permeability through joint on macrocell corrosion", Journal of JSCE, No.578, pp.31-42 (1997).

12) S. Komatsu, S. Miyazato, Y. Maeda, T. Ohshiro and T. Matsui, "Proposal of prevention method for re-degradation near knock down part using silane type penetrants", Journal of JSCE, Vol.70, No.1, pp.19-28 (2014).

13) S. Miyazato, N. Otsuki and A. Konagai, "The experimental and theoretical investigation of macrocell current measurement method using special divided steel bar", Proceedings of JCI, Vol.23, No.2, pp.547-552 (2001).

14) Japan Concrete Institute, "Technical report on electrochemical measurements based on physicochemical theory" CD-ROM, (2015)

15) Corrosion Association, "Introduction to electrochemistry to understand corrosion", 23rd technical seminar, pp.13-25 (2000).

16) Y. Akira, T. Yamaji and H. Kobayashi, "Long-term durability of the concrete of the tide zone using seawater as a mixing water”, Proceedings of JCI, Vol.34, No.1, pp.820-825 (2012).

17) M. Suzuki, N. Fukuhara and T. Maruya, "Establishment of a coupled analysis between structure and reinforcement corrosion for predicting deterioration of reinforced concrete structure by salt damage", Journal of JSCE, Vol.70, No.3, pp.301-319 (2014). 
18) T. Hatanaka, S. Miyazato and S. Mizutani, "Influence of application quantity of penetrants on reduction of macrocell corrosion", Proceedings of the 57th Japan Congress on Materials Research, pp.81-82 (2013).
19) A. Yamaguchi, S. Miyazato and K. Yamamoto, "Influence of electrical resistance of patch repair material on anti-corrosion performance by sacrifice anode material", Proceedings of JSMS Symposium on Concrete Structure Scenarios, Vol.9, pp.315322 (2009). 